Working Papers on The Nature of Evidence:

How Well Do 'Facts' Travel?

No. 02/05

\title{
A Dreadful Heritage: Interpreting Epidemic Disease at Eyam, 1666-2000
}

\author{
Patrick Wallis
}

(C) Patrick Wallis

Department of Economic History

London School of Economics 


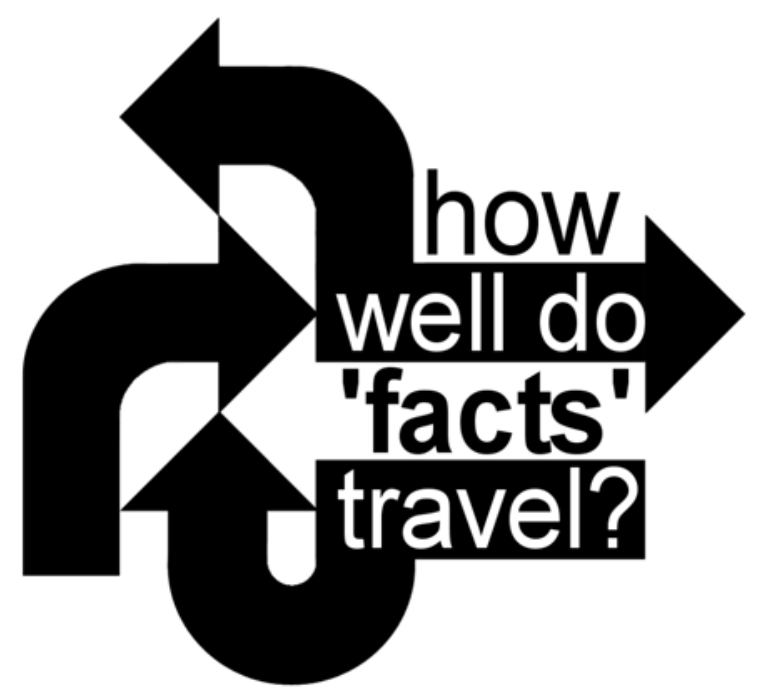

"The Nature of Evidence: How Well Do 'Facts' Travel?" is funded by The Leverhulme Trust and the ESRC at the Department of Economic History, London School of Economics.

For further details about this project and additional copies of this, and other papers in the series, go to:

http://www.Ise.ac.uk/collection/economichistory/

Series Editor:

Dr. Jonathan Adams

Department of Economic History

London School of Economics

Houghton Street

London, WC2A $2 \mathrm{AE}$

Tel: $\quad$ +44 (0) 2079556727

Fax: $\quad$ +44 (0) 2079557730 


\title{
A Dreadful Heritage: Interpreting Epidemic Disease at Eyam, 1666-2000. ${ }^{1}$
}

Patrick Wallis

\begin{abstract}
Suffering has sanctified its claim to notice, and the curious and enquiring traveller feels a melancholy pleasure in tracing out the records of the ravages made in this little village by that depopulating scourge of nations ${ }^{2}$
\end{abstract}

\begin{abstract}
Eyam is an epicentre of Europe's plague heritage. Every year, tens of thousands of people visit the Derbyshire village, drawn by stories of its catastrophic plague and the heroic response it elicited. The story they are told - of a self-imposed quarantine preventing disease spreading to the surrounding area - is an exemplary narrative of a selfless community under strong, positive leadership. But although the plague of Eyam in 1666 is one of the most famous outbreaks of epidemic disease in British history, the narrative is largely a fiction; produced not by doctors, but by poets, writers, and local historians. Eyam's ongoing celebrity is indebted to a combination of literary effort and contemporary events. During the late-eighteenth and nineteenth centuries, a tradition was established, manipulated, and reshaped to fit changing literary and historical fashions. The construction of the Eyam plague story offers an unusually clear case study in the social and intellectual dynamics of the creation of heritage and history. This paper examines the process by which this narrative emerged and was repeatedly reconstructed over three centuries, and its subsequent transformation into a prominent part of English heritage. Through this close focus we can trace in some detail what Raphael Samuel called the "imaginative dislocations which take place when historical knowledge is transferred from one learning circuit to another."
\end{abstract}

\footnotetext{
${ }^{1}$ I am grateful to the Leverhulme Trust for supporting the research on which this paper is based. I have benefited greatly from discussions about Eyam with Rosie Blau, Simon Ditchfield, Mark Jenner, Mary Morgan, Margaret Pelling and Tim Strangleman.

${ }^{2}$ Ebenezer Rhodes, Peak Scenery; or the Derbyshire tourist. London, 1824, p.31.
} 
Every year, tens of thousands of people visit the village of Eyam in Derbyshire, drawn by stories of its catastrophic plague and the heroic response it elicited. Like Oberammergau's Passion Play, or Mary King Close in Edinburgh, Eyam is an epicentre of Europe's plague heritage. The standard account of its plague that found its fullest expression in a number of histories, poems and novels produced in the mid-nineteenth century tells how, in late 1665, the disease reached Eyam, concealed in a box of old clothing sent to the village tailor from London, then in the last throws of its own Great Plague. The earliest deaths in the village were sporadic and the death rate declined in the winter. But hopes that Eyam had escaped the scourge were dashed in spring, when the toll mounted quickly. By June 1666, the village's rector, William Mompesson, had apparently realised that the villagers must act to prevent the plague spreading to neighbouring parishes. Supposedly at his suggestion, the villagers quarantined their village. No-one would leave until the disease was spent. The Earl of Devonshire, whose estate at Chatsworth was a few miles away, is said to have supported the plan. He arranged for supplies to be left at the boundary of the quarantine, for which the villagers left payment in pools of vinegar or streams to prevent it carrying the contagion. Mompesson was, so we are told, leader, comforter and healer to the villagers. Alongside him worked Thomas Stanley, whose role is somewhat ambiguous as he had been rector of Eyam until his ejection from the post in 1662 for non-conformity. Normal life in the village was shattered by the epidemic. Religious services were held outdoors, in a green and shady delft which became known as the 'Cucklet Church'. Bodies were interred near the place of their death, rather than in the churchyard. Mompesson survived the epidemic, but his wife Catherine died tragically in late August. Fortunately their children had been sent away to Yorkshire where they were safe from the plague. Like their 
rector, the villagers paid a high price for their heroic isolation: according to these accounts, 259 of a population of 330 died.

Today, the plague of Eyam in 1666 is one of the most famous outbreaks of epidemic disease in British history. Accounting for Eyam's presence within the popular narrative of English history might not seem difficult; the horror of the village's epidemic is bluntly argued by the record of mortality in its parish records. But trauma is no guarantor of historical respect or interest, and Eyam did not become instantly regarded. ${ }^{3}$ Indeed, it was almost forgotten in the eighteenth century. Since then, the story has been frequently retold in poems, novels and plays. There are even three musicals, a children's television drama, and at least one folk song. ${ }^{4}$ Yet, like London's 'Great Plague' of 1665 - in fact a less severe outbreak than the epidemics of 1603 and 1625 - the events at Eyam were not all that they seem, and certainly not all that is remembered or commonly retold. The account given above brings together the bare bones of the version that was popularised in the nineteenth century and which survived for much of the twentieth century. But these bones have themselves been re-arranged and sometimes added to or discarded, while the flesh of the story built upon them has been moulded into even more varied forms. This paper examines the process by which this narrative emerged and was repeatedly reconstructed over three centuries and its transformation into a prominent part of English heritage. Through this close focus we can trace in some detail what Raphael Samuel

\footnotetext{
${ }^{3}$ Peter Novick, The Holocaust and Collective Memory: The American Experience, London, 1999.

4 Darren Vallier, 'A Ring of Roses', first performed at the Savoy Theatre, 1997; Andrew Peggie and Stephen Clark, 'Eyam: A Musical', premiered at the Bridewell Theatre, London, 1998; Eddie Brierley and Peter Robinson, 'Ring of Stones', premiered at the Dancehouse, Manchester, 2001. The children's programme 'All Fall Down', written by Hannah Lee (aged 12), produced by the Incredible Story Studio for Disney Channel. Roy Bailey, 'Roses of Eyam', on his album 'Past Masters', Fuse Records, 1998.
} 
referred to as the 'imaginative dislocations which take place when historical knowledge is transferred from one learning circuit to another'. ${ }^{5}$ Eyam's ongoing celebrity is, as I show, indebted to a combination of literary effort and contemporary events, particularly, but not exclusively, involving the threat of disease, during the late eighteenth and nineteenth centuries. During this period a tradition was established, manipulated and reshaped to fit changing literary and historical fashions, while the fabric of the village itself was adapted to suit the tourist trade on which it became increasingly dependent. In some ways, Eyam's history might be compared to that of the 'Great Plague' of London, which also owes much of its notoriety to literary investment, particularly Daniel Defoe's History of the Plague Year (1722), written at a time when an epidemic in Marseilles made it seem almost inevitable that plague would again reach London. However, while Defoe wrote of events still just within living memory, Eyam did not find its amanuensis until the mid-eighteenth century. Then, after a period of near neglect, its story was gradually constructed in a number of different kinds of text, from verse to guidebook. The construction of the Eyam plague story offers an unusually clear case study in the social and intellectual dynamics of the creation of heritage and history. That the story of the plague of Eyam did not become widely disseminated until so long after the event allowed it to develop without the influence of a dominant 'authentic' interpretation from the time of the epidemic itself. ${ }^{6}$ One further significant consequence of the chronological lag between event and narration was that accounts of Eyam were carved

\footnotetext{
${ }^{5}$ R. Samuel, Theatres of Memory. Vol. 1: Past and Present in Contemporary Culture, London, 1993, p.8.

${ }^{6}$ Eyam thus differs from the early modern plague discourses and memories that have been studied by Colin Jones and Anne Carmichael: Colin Jones, 'Plague and Its Metaphors in Early Modern France', Representations, 53:1, Winter 1996, pp.97-127; Anne G. Carmichael, 'The Last Past Plague: The Uses of Memory in Renaissance Epidemics', Journal of the History of Medicine, 53:2, Spring 1998, pp.132-60. On memory: Jan Assman, 'Collective Memory and Cultural Identity', New German Critique, 65 (1995), pp.125-33.
} 
into shape after the threat of plague, at least, had to an extent retreated. The immediate justification of actions against plague, and the power and reputation of those involved, was no longer the issue. Appropriate responses to epidemics and disease did continue to be an issue in the retelling and reception of the Eyam story, but they run in parallel with other significant issues, particularly regarding local and national identity, the nature of heroism, and the nature of leadership in a community.

Recovering the history of the changing representation of Eyam plague over the late eighteenth, nineteenth and twentieth centuries is a complex challenge involving the consideration of multiple texts over a long period. The main sources discussed below are given in table 1 , loosely grouped according to the section in which they are discussed. As this indicates, the paper broadly follows a chronological order. It begins with an examination of what is - and what is not - known of the plague itself from contemporary sources. It then considers the two earliest descriptions of the plague, written in the early eighteenth century. The rediscovery and earliest public celebrations of the epidemic occurred in later eighteenth century descriptions written by William Seward and Anna Seward; these are discussed next. This is followed by a consideration of the effusion of interest that followed their publications in the nineteenth century and its relationship to the broader construction of an epidemic historiography and set of plague tropes. The production and popularisation of the village as a heritage site after the 1866 bicentenary is the subjects of the following part. Finally, we look at the gradual development of a more critical, less laudatory approach in the twentieth century. 
Table 1: Principal texts discussed in the paper

Primary sources

1666

William Mompesson's three letters, 1666

Parish register, transcript from 1705

Sheffield constables accounts, 1666

Subsequent accounts

Early $18^{\text {th }}$ century Bagshaw, De Spiritualibus Pecci, 1702

Mead, Discourse, 1722

Later $18^{\text {th }}$ century European Magazine, 1790

William Seward, European Magazine, 1793, repr. Anecdotes, 1795-7

Anna Seward, Poetical Works, 1810 (composed 1766)

Early to mid $19^{\text {th }} \quad$ Holland, Village of Eyam, 1821

century

Rhodes, Peak Scenery, 1824

W \& M Howitt, Desolation of Eyam, 1827

Ward, Guide to the Peak, 1827

Roberts, Eyam, 1834

Adam, Gem of the Peak, 1838

Hall, Peak and the Plain, 1838

Wood, History and antiquities of Eyam, 1842

The Tale of Eyam, 1888

Late 19 th-early $20^{\text {th }}$

Creighton, History of Epidemics, 1891

century histories

and guides

Fletcher, The plague-stricken Derbyshire village, 1924

Eyam and the Plague: a guide, nd

Daniel, History of Eyam, 1932

WRB, 'William Mompesson', Annals of Medical History, 1939

Later $20^{\text {th }}$ century

Bowen, God and the Wedding Dress, 1938

fictional accounts

Dennys, Isolation at Eyam, 1954

Taylor, The Roses of Eyam, 1970

Brooks, Year of Wonders, 2002

Eyam: A Musical, 1995

\section{The Evidence Of The Epidemic}

The idea of Eyam's significance was established and perpetuated by creative as much as historical interpretations, to the extent that we can draw a line between the two genres in this case. Both drew upon, and in turn often extended, the village's striking legacy: the plague narrative 
formed from shards of fiction, memory and history. The different origins of the various elements of this account have now largely been forgotten. Indeed, they were sometimes obscured deliberately. Yet, much of the coherency of the traditional account dissolves when examined closely. If we restrict ourselves to the earliest sources on the epidemic we find a much more slender story. Only a limited body of contemporary evidence survives, the principal artefacts being three letters by William Mompesson, which powerfully convey the personal impact the death of Catherine Mompesson had on him, and, in passing, mention some of the villagers' responses. ${ }^{7}$ There is a copy of the parish register, made around $1705 .{ }^{8}$ Finally, there is the landscape of the parish, with its scattering of tombs. Two of the earliest accounts claim indirect connections through their authors' conversations with the sons of Mompesson and Stanley. ${ }^{9}$ Beyond this scanty body of evidence, a voluminous body of 'oral tradition' published in the early nineteenth century by the local historian and tax collector William Wood provides the bulk of the sources. ${ }^{10}$

Despite such weak foundations, cracks in the story's façade began to be spotted only relatively recently. In the 1970s, Leslie Bradley showed that Eyam's mortality was less extraordinary than had been thought:

\footnotetext{
${ }^{7}$ One of the letters is now lost. Batho also identified a letter from Saville to Mompesson, dated 21 December 1666, in the Borthwick Institute of Historical Research, University of York, CPH, 4549: G. R. Batho, 'The Plague at Eyam: A Tercentenary Re-Evaluation', Derbyshire Archaeological Journal, 84:1 (1964), pp.8191.

${ }^{8}$ John G. Clifford and Francine Clifford (eds), Eyam Parish Register, 1630-1700, Chesterfield, 1993.

${ }^{9}$ Mompesson's son helped Mead: Richard Mead, A Short Discourse Concerning Pestilential Contagion, and the Methods to Be Used to Prevent It, 8th edn., London, 1722, pp.135-7. Stanley's son helped Bagshaw: William Bagshaw, De Spiritualibus Pecci, London, 1702, pp.61-64.

${ }^{10}$ William Wood, The History and Antiquities of Eyam, 1st edn., London, 1842. Wood's oral traditions are suspect. A much briefer account was gathered in the parish in the 1780 s which omits any mention of Mompesson and isolation: James Pilkington, $A$ View of the Present State of Derbyshire; with an Account of Its Most Remarkable Antiquities, 2 vols., Derby, 1789, ii, 412. Similarly suggestive is the lack of a reference to Eyam in a detailed account of the 1665 plague at Derby: William Hutton, The History of Derby to the Year 1791, London, 1791, pp.233-35
} 
around $64 \%$ of families escaped the plague, and no more than half the population died. ${ }^{11}$ The events of the epidemic have received less corrective attention - indeed, Eyam has largely existed in a hinterland outside academic history between local, antiquarian accounts and literary re-imaginings. The plague largely enters the purview of national histories as an anecdote or illustration, extraneous to the main course of events. In the local history established in the nineteenth century it is dominant, outshining all other reference points in the village's past. Nonetheless, several crucial points have emerged. A central point of traditional accounts, that the villagers were the agents of their own quarantine, has been questioned by Paul Slack, who has pointed out that the cordon sanitaire around Eyam was similar to controls imposed on a number of parishes and towns in the 1660s, and before, in exchange for supplies of food. ${ }^{12}$ Suggestively, the earliest sources on the village are all vague on the subject of the isolation, while Sheffield employed constables to keep 'people from Fulwood Spaw in the tyme yt the sickness was att Eam'. ${ }^{13}$ Certainly, as an extremely poor industrial parish populated by miners who were more reliant on imports of food than many villages, Eyam was particularly vulnerable to such external pressure. ${ }^{14}$ This also chimes with another unrecognised ambiguity in the story: that, according to Wood, writing in the nineteenth century, the isolation began only in June, eight months after the epidemic began. It is also possible that the quarantine was more limited than is generally presumed: although Eyam was almost

\footnotetext{
${ }^{11}$ Leslie Bradley, 'The Most Famous of All English Plagues: A Detailed Analysis of the Plague at Eyam, 1665-6', in The Plague Reconsidered, Local Population Studies, 1977, pp.63-94. On the long-term impact: Philip Race, 'Some Further Considerations of the Plague at Eyam', Local Population Studies, 54:1, Spring 1995, pp.56-65.

${ }_{12}$ Paul Slack, The Impact of Plague in Tudor and Stuart England, London, 1985. See also: Mary Dobson, Contours of Death and Disease in Early Modern England, Cambridge, 1997, p.281; John Hunter, Hallamshire: The History and Topography of the Parish of Sheffield, in the County of York, London, 1819, p.112.

13 'Sheffield Constables Accounts, 1666'. Sheffield City Archive, JC 905.

${ }^{14}$ Andrew Wood, The Politics of Social Conflict: The Peak Country, 1520-1770, Cambridge, 1999.
} 
uniformly poor, those few villagers with slightly more wealth suffered disproportionately few deaths, suggesting that they had perhaps fled. ${ }^{15}$

More speculative questions arise over the heroic rector Mompesson's relationship with the villagers. He had taken over the rectory in Eyam in 1664, the nominee of the new lord of the manor, Sir George Saville. Meanwhile, Thomas Stanley, the rector of Eyam during the interregnum, remained in the village. Stanley had significant local support. ${ }^{16}$ Yet Mompesson has the leading role in nearly all accounts of plague. There is some contemporary support for this. Saville presumably relying on Mompesson's description of events and knowing of the death of his wife - himself attributed the end of the plague to the rector's 'care to a place that hath beene soe sorely afflicted', praising him as 'much a Martyr all this while as if you had dyed for your flock', having 'sacrificed the pleasure of your life to your duty'. ${ }^{17}$ Yet the earliest, albeit partisan, printed version of the plague story ignored him in favour of Thomas Stanley. Mompesson also sent his children to safety in Yorkshire before the quarantine was established. We might well wonder how accepted he was within the village.

\section{The Earliest Accounts Of The Plague}

Little is thus stable or definite in the story of Eyam's plague. The limited direct evidence from 1665-1666 would be less striking if the story had been quickly recorded and circulated. However, the story of Eyam plague was known as, at most, a minor anecdote before the last decade

\footnotetext{
${ }^{15}$ According to the 1664 hearth tax assessors, only 59 of 160 Eyam households were wealthy enough to be chargeable. Among the chargeable households, 22 of 51 households with one hearth (43\%) had plague deaths, while only 1 of the 6 with two or more hearths did (17\%): Public Record Office, E 179/94/403; Eyam Parish Register. ${ }^{16}$ In 1662, 69 villagers petitioned Saville to keep Stanley in office: Nottinghamshire Record Office, DDSR 221/94/39.

${ }^{17}$ Borthwick Institute, $\mathrm{CPH}, 4549$.
} 
of the eighteenth century, despite the village's location in the heart of the Peak District, already a major English tourist destination. Nevertheless, the extensive tourist literature on Derbyshire omits any mention of the plague village, even as a brief anecdote to horrify or bemuse those who passed the turning to the village on the road between Chatsworth and Chesterfield. ${ }^{18}$ William Bray, who at least mentioned Eyam in his itinerary, described the ancient cross in its churchyard, but not the cause of the graves which surrounded it. ${ }^{19}$

Admittedly, Eyam plague was very occasionally mentioned in religious and medical debates during the late seventeenth and early eighteenth centuries. The two brief accounts that were the foundations for these comments differ markedly in tone from later eighteenth century renditions. It is striking how many details remain unclear and that the authors showed only limited interest in the epidemic. The leadership of Stanley and Mompesson, respectively, is praised, but there is no hint or romance, tragedy, or even of distinction accruing to the rest of the community.

The earliest printed account, describing Stanley remaining to help the sick during the epidemic, forms part of a genre of non-conformist writing in which plague provides a testimony to their parochial commitment, despite legal exclusion. ${ }^{20}$ Indeed, it is little more than a

\footnotetext{
${ }^{18}$ Eyam is missing from the main accounts of Derbyshire by travellers: Celia Fiennes, The Journeys of Celia Fiennes, ed. C. Morris, London, 1949; James Brome, Travels over England, Scotland and Wales, 2nd edn., London, 1707; John Macky, A Journey through England, 5th edn., London, 1732; Samuel Simpson, The Agreeable Historian, or the Compleat English Traveller, London, 1746; William Stukeley, Itinerarium Curiosum, London, 1724; Phillip Carl Moritz, Journeys of a German in England in 1782, ed. and trans. Reginald Nettel, London, 1965; C. Bruyn Andrews (ed.), The Torrington Diaries, London, 1934; Thomas Newte, Prospects and Observations on a Tour in England and Scotland, London, 1791; Barthelemi Faujas De Saint-Fond, Travels in England, Scotland, and the Hebrides, London, 1799.

${ }^{19}$ William Bray, Sketch of a Tour into Derbyshire and Yorkshire, 2nd edn., London, 1783, pp.178-9

${ }^{20}$ Patrick Wallis, 'Plagues, Morality and the Place of Medicine in Early Modern England', English Historical Review (forthcoming).
} 
description of how the Earl of Devonshire had rebuffed demands that he force Thomas Stanley to leave Eyam with a reference to the nonconformist's actions during the plague, saying:

It was more reasonable, that the whole Country should in more than Words testifie their Thankfulness to him [Stanley], who together with his Care of the Town, had taken such Care, as no one else did, to prevent the Infection of the Towns adjacent. ${ }^{21}$

Devonshire's patronage of Stanley, more than the plague, made this worthy of inclusion to the author, the non-conformist minister William Bagshaw. Such favour from a leading figure, in theory obliged to enforce the laws making non-conformists leave their former parishes, was a minor political triumph for the non-conformist cause, particularly because the earl's family were part of the whig aristocracy from whom the nonconformists were seeking support. ${ }^{22}$ Bagshaw recognised the severity of the epidemic at Eyam and its successful containment, although he is unique in implying that Mompesson played no part. However, he did not imply the village's experience was unique, heroic, or even self-selected rather than imposed from outside.

A similar blindness to the very aspects of the epidemic that would later be most notable can be observed in the other early published account of Eyam, included by the royal physician Richard Mead in the eighth edition of his Short Discourse Concerning Pestilential Contagion (1722). ${ }^{23}$ Mead took Eyam as an example to establish his 'Precepts'

\footnotetext{
${ }^{21}$ Bagshaw, Spiritualibus Pecci, p. 64.

22 This also seems to have been Edward Calamy's motive for incorporating Stanley into his work: Edward Calamy, An Abridgment of Mr Baxter's History of His Life and Times, London, 1702, p.391. Calamy dedicated this to the Marquis of Hartington, heir of the Duke of Devonshire. See also: A. G. Matthews (ed), Calamy Revised, Oxford, 1934, p.459. Stanley was not in Richard Baxter's list of non-conformists, on which Calamy's work was based: Richard Baxter Reliquiae Baxterianae, London, 1696, part iii, pp.90ff.

${ }^{23}$ Mead, Discourse, $8^{\text {th }}$ edn, pp.135-7. Editions one to seven (all 59pp.) were published in 1720. The eighth edition trebled in size, to 150pp. On the debate: Slack, Plague; James C. Riley, The Eighteenth Century Campaign to Avoid Disease, Basingstoke,
} 
against the plague. His account centred on three stages of action: removing the sick to separate 'Hutts or Barracks'; securing provisions from Devonshire; and ensuring 'that no-one should go out of the Parish'. Although attributed to Mompesson, this neatly echoes Mead's own plan, drawn up in $\mathbf{1 7 2 0}$ for the government in anticipation of the plague spreading from the major epidemic in Marseilles. The legislation embodying this scheme had been controversial and short-lived. Mead's main purpose in revising his Discourse was to defend his proposals and the theories behind them. Read in this light, Mead's emphases seem tactical. Given that a major criticism of his plans was that quarantined communities would be neglected, it seems no accident that Devonshire's agreement to furnish provisions is tied to the village's closure. The plague's transmission in a box of clothing - first mentioned here similarly bolstered his position in the debate over the causes of plague. Notably, Mead does not single out Mompesson's behaviour as heroic, despite having received some of his information from the rector's son (which also may explain the absence of any mention of Stanley). Mompesson had simply done what Mead expected of crown officials and clergy during epidemics.

\section{The Sewards' British Hero}

Eyam's relative anonymity for much of the eighteenth century stands in striking contrast to its later fame. It was not until the last decade of the century that it began to attract greater interest, a change related to a fortuitous conjunction of shifts in literary and historical taste, and the chance interest of several literary figures. Eyam's plague narrative was to

1987. One of Mead's acolytes, Thomas Short also mentioned Eyam, but his account was wholly based on Mead's Discourse: T. Short, A General Chronological History of the Air, 2 vols., London, 1749, i, p.340. 
become popular as a synthesis of literary romanticism with the sentimental, geographically particular, engagement with history that was being formed at this time. ${ }^{24}$ It provided the framework around which another evocative fragment of the past could be woven: a tamed catastrophe that, like medieval or modern wars, became a tableau for unproblematic heroism. In this form, the story of Eyam became part of a new vision of the Peak District, and of a general conception of Englishness which emphasised its roots in a mythicised heroic past, continuing particularities of character, and its distinctiveness from Catholicism and the continent. ${ }^{25}$

Eyam's relationship to an idea of English character was most overt at the beginning of this process. In the wake of the French Revolution, Eyam's story became a concern for those readers of the European Magazine unimpressed by the favourable biographical sketches of French Catholic clergy it had included in a series lamenting the fall of the ancien regime. (Deceased or deposed aristocrats proved much less controversial.) Among those eulogised was the Bishop of Marseilles, whose uninterrupted leadership of his flock during the plague of 1720 had been widely lauded across Europe. ${ }^{26}$ Reluctant to allow any unqualified merit in a Catholic priest, one reader, 'Curiosus', included Mompesson in a description of three Englishmen 'who have distinguished themselves in this country as much as that illustrious Frenchman did in his, but who

\footnotetext{
${ }^{24}$ On conceptions of the past: Mark S. Phillips, Society and Sentiment: Genres of Historical Writing in Britain, Princeton, 2000; Stephen Bann, The Clothing of Clio: A Study of the Representation of History in Nineteenth-Century Britain and France, Cambridge, 1984; Hayden V. White, Metahistory: The Historical Imagination in Nineteenth-Century Europe, Baltimore, 1975; A. Dwight Culler, The Victorian Mirror of History, New Haven, 1985; J. W. Burrow, A Liberal Descent: Victorian Historians and the English Past, Cambridge, 1981.Work on local histories is scarcer, but see: Rosemary Sweet, The Writing of Urban Histories in Eighteenth-Century England, Oxford, 1997.

${ }^{25}$ See: Lowenthal, Heritage, pp.97-98; Alice Chandler, A Dream of Order: The Medieval Ideal in Nineteenth-Century English Literature, London, 1971.

${ }^{26}$ European Magazine, xvii, April 1790.
} 
have not enjoyed his celebrity of reputation'. ${ }^{27}$ The account was based on Mead, but some local knowledge was apparent in the mention of a eulogium on this 'good shepherd' given in 1766 by Thomas Seward, rector of Eyam, with such force 'that all who heard it were dissolved in tears'.

This patriotic comparison with the Bishop of Marseilles gave impetus to the fuller account of the plague that the writer William Seward - not a relation of the village rector, although an acquaintance of Anna Seward - published in the magazine in 1793 , following the appearance of several notes and corrections. ${ }^{28}$ Including Mompesson's three letters of 1666 , his version was later reprinted and widely circulated in one of the several volumes of collected biography and anecdote that Seward published. ${ }^{29}$ In it, Seward began the transformation of the Eyam story into the version that became famous. Most significantly, whereas to Richard Mead, Eyam had been an example of correct, replicable behaviour, now Mompesson is a hero. Indeed, he can hardly be anything less, for Seward's account of his virtues is designed to show how he exceeded the valour of the Bishop of Marseilles. As he states:

Old and Modern England...for we trust that it is nearly the same as it has ever been, may congratulate herself in having cherished in her bosom a Parish Priest, who, without the splendour of character,

\footnotetext{
${ }^{27}$ The other examples came from the 1665 plague of London: European Magazine, xvii, June 1790, pp.415-6. 'Curiosus' was not alone in his attitude. In 1827, Charles Swan, the earliest English translator of Manzoni's I Promessi Sposi similarly cut a biographical description of Cardinal Borromeo's activities during the Milan plague: Augusta Pallotta, 'British and American Translations of I Promessi Sposi', Italica, 50:4, Winter 1973, pp.485-6. An untroubled comparison between the bishop and the mayor of London was made by Erasmus Darwin in The Botanic Garden, London, 1789, part 2, lines 435-9.

${ }^{28}$ Seward's description is: European Magazine, vol. xiv, July 1793, pp.62-65, Aug 1793, pp.118-20. Prior notes include: Ibid, xvii, July 1790, p.23; ix, Jan 1791, p.17. On Seward: Dictionary of National Biography.

${ }^{29}$ William Seward, Anecdotes of Some Distinguished Persons, 5 vols., London, 17957, ii, 21-38. Five editions appeared within ten years. It is unclear if Seward was the author of the original piece.
} 
and the extent of persons over whom M. de Belsance [the Bishop of Marseilles] distributed the blessings of his pastoral care, watched over the smaller flock committed to his charge at no less risque of life, and with no less fervour of piety and activity of benevolence.

Paradoxically, Mompesson's modest status becomes a sign of his character - and by extension that of the English in general. In contrast to the pomp and authoritarianism of Catholic France, Mompesson exemplifies a diligent, disciplined, Christian masculinity - a symbolic role in which he appeared frequently thereafter. ${ }^{30}$

As well as establishing Mompesson's heroism, William Seward also elaborated several other key details. He makes it clear that Mompesson and his wife argued over fleeing the plague, and that she refused to leave if he stayed. He also describes how Mompesson's 'persuasion and authority' 'prevailed upon' the villagers, convincing them to stay. However, beyond trumping the bishop, Seward's fascination with the plague centres on the tragic consequences it had for Mompesson and his family, made apparent in the letters that the rector wrote for his children. These gave the empathetic reader a privileged insight into his extreme emotional and spiritual experience. As Seward noted: 'I hope that neither I nor my friends shall ever know that person who can read them without tears'. To read about Eyam was to take a sentimental, morally didactic journey into the past. ${ }^{31}$ In a climate of historical writing which paid new attention to the local, the familiar and the intimate, and, as Mark Phillips argues, made 'sympathetic identification... one of the

\footnotetext{
${ }^{30}$ See for example: Charlotte M. Yonge, A Book of Golden Deeds of All Times and All Lands, London, 1864, pp.291-94. Jeremy Gregory, 'Homo Religiosus: Masculinity and Religion in the Long Eighteenth Century', in Tim Hitchcock and Michelle Cohen (eds) English Masculinities, 1660-1800, Harlow, 1999, pp.85-110; Herbert L. Sussman, Victorian Masculinities: Manhood and Masculine Poetics in Early Victorian Literature and Art, Cambridge, 1995; N. Vance, The Sinews of the Spirit: The Ideal of Christian Manliness in Victorian Literature and Religious Thought, Cambridge, 1985.

${ }^{31}$ European Magazine, July 1793, xiv, pp.62-66; August 1793, xiv, 118-20. On the significance of empathy, see: White, Metahistory, pp.38-9.
} 
pleasures of historical reading', the village's tragedy thus became a worthy part of history in its own terms - not just an illustration or example in a broader case, as narrated by Mead or even Bagshaw. ${ }^{32}$

Although William Seward had identified the tragic choice and heroic sacrifice that would give the plague story its durability, his interpretation was soon superseded. In 1810, the noted poet Anna Seward's more expansive and romantic account appeared posthumously. Born in Eyam before her father moved to Lichfield, Anna Seward was the daughter of the parish's rector, Thomas Seward. Along with him, she saw Mompesson's letters around the centenary of the epidemic: her long letter describing the plague is dated February 1765.

In this letter, Anna Seward created in outline the structure and valency imitated in most nineteenth century accounts. Some aspects, including the form of the decision about isolation, and a comparison with the bishop of Marseilles, are much as in William Seward's description. However, she further emphasised its tragic aspect, and paid much more attention to place and marital duty, both important to sentimental thought. Her new concern with the remote and beautiful setting of the village high in the mountains of the Peak District heightens the impact of plague as a natural horror: even the lime-kilns and smelting houses which sully the dale in daytime 'seem so many small volcanoes in the night'. She also sharpened the dramatic social impact of the 'pestilential calamity'. This is particularly apparent in her reconstruction of Mompesson 'preaching to his alarmed and distressed flock', which ends with the comment: 'How solemn, how pathetic, must have been his exhortations in those terrific hours! ${ }^{33}$ Although absent from earlier accounts, these sermons - like the landscape - were a subject which few who wrote after her ignored.

\footnotetext{
${ }^{32}$ Phillips, Society and Sentiment, p. xii.

${ }^{33}$ Anna Seward, The Poetical Works of Anna Seward, ed. Walter Scott, 3 vols., Edinburgh, 1810, i, clvii, clxi.
} 
Perhaps most importantly, Anna Seward reshaped and gendered the story, a process Greg Kucich has recently highlighted in the work of many contemporary women writers. ${ }^{34}$ Her account makes the romantic, marital love of the rector and his 'beloved wife' as important a factor as civic duty. Catherine Mompesson is much more prominent here, torn between the irreconcilable responsibilities of a mother to her children and a wife to her husband. Her decision to stay is put beyond question by her death, and exemplifies the triumph of virtue and duty. Indeed, her death is framed as a sacrifice to her marriage and the village; to Anna Seward, it is the greatest cost suffered by the community. Through this broadening of the story into the domestic domain, and other tweaks, she disposes the bare elements of the story to form the skeleton of a romance which reaches its twin climaxes with Catherine's death and William Mompesson's transcendence of the world in the aftermath of the epidemic. This last emotional pinnacle was apparent in his 'pious, affectionate, mournful, and pathetic' letters. ${ }^{35}$

Although overtly factual, Anna Seward's account of the epidemic was, in large part, a historical fiction. Appropriately, it was published posthumously in a successful edition of her collected poetry and literary correspondence edited by Walter Scott, then best known as a poet but soon to become famous for his epic historical novels. Scott notes in a somewhat ungenerous footnote that William Seward had earlier printed

\footnotetext{
${ }^{34}$ Greg Kucich, 'Romanticism and the Re-Engendering of Historical Memory', in Matthew Campbell, Jacqueline M. Labbe, and Sally Shuttleworth (eds), Memory and Memorials, 1789-1914, London, 2000, pp.15-29. See also: Devoney Looser, British Women Writers and the Writing of History, 1670-1820, Baltimore, 2000; Stuart Curran, 'Women Readers, Women Writers', in Stuart Curran (ed), The Cambridge Companion to British Romanticism, Cambridge, 1993, p.191; Gary Kelly, Women, Writing, and Revolution, 1790-1827, Oxford, 1993.

${ }^{35}$ This letter was dated 25 Feb 1765: Seward, Poetical Works, pp.clxvi-clxxix. The significance of documents and evocation is discussed in: Phillips, Society and Sentiment, pp. 98-102 On romantic form, see: Northrop Frye, Anatomy of Criticism: Four Essays, Princeton, 1957; White, Metahistory.
} 
copies of Mompesson's letters, but comments that he had introduced them:

in a cold, uninteresting manner....neither his heart nor his imagination seem to have caught the least glow from vestiges so likely to have warmed them. He does not even mention the beautiful, romantic dingle ${ }^{36}$

That Anna Seward's approach was better suited to Scott's tastes is unsurprising. As well as sharing an interest in blurring the separation of historical fact and fiction, parallels exist between the devices they both employ to convey historical authenticity to literary texts. Anna Seward's hybrid account, although brief and more historical, incorporates many of the devices Scott would later used to great effect in her promotion of Eyam as a pastoral stage for disaster, the interpolation of documentation and narrative, and the construction of Mompesson as a solitary hero figure. $^{37}$

\section{The Fascination Of Plague In The Nineteenth Century}

Together, William and Anna Seward's descriptions of the plague fostered interest in Eyam. They had settled the outlines of the narrative and smoothed out much of its former ambiguity. Subsequent versions of the story that appeared from the early 1820s, largely by local writers, formed a gradual blossoming of the romanticised, heroic history they had established. ${ }^{38}$ Works on Eyam plague ranged from epic poems ${ }^{39}$ to tourist

\footnotetext{
${ }^{36}$ Seward, Poetical Works, i, clx.

${ }^{37}$ Bann, Clio, pp.144-45. See also: Anne Rigney, Imperfect Histories: The Elusive Past and the Legacy of Romantic Historicism, Ithaca, 2001, pp.53, 107; Megan P. Stitt, Metaphors of Change in the Language of Nineteenth Century Fiction, Oxford, 1998. ${ }^{38}$ In 1818, Mead could still be taken as the sole source on Eyam: J. Britton and E. W. Brayley, The Beauties of England and Wales, 19 vols., London, 1801-1818, iii, pp.xx$x \mathrm{x}$.
} 
guidebooks, ${ }^{40}$ and potted histories. ${ }^{41}$ Although often much longer, most borrowed heavily from Anna Seward's account, maintaining the balance she had introduced between the village's isolation and the Mompesson's doomed love. The expansions they contain, often purportedly from oral traditions, change nothing substantial. Even wholly new elements, such as the tale of the rustic lovers Roland and Emmot tragically separated by the epidemic (who bear suggestive similarities to the lovers in John Wilson's popular poem, City of the Plague), had little effect on the overall tenor. ${ }^{42}$ The influence of later literary styles can be identified in some versions, particularly in the gruesomely gothic descriptions of the haphazard burial of plague victims. ${ }^{43}$ However, nearly all continued to blur the boundaries between historical and fictional writing, emphasising superficially unmediated engagement with contemporary letters or conversations. ${ }^{44}$ Poems such as John Holland's The Village of Eyam (1821) included the text of Mompesson's letters among their endnotes. ${ }^{45}$ Conversely, William Wood's History of Eyam is peppered with imagined dialogues between leading characters. These literary shifts in register from direct evidence, such as the parish register and Mompesson's

\footnotetext{
39 John Holland, The Village of Eyam: A Poem in Four Parts, Macclesfield, 1821; William and Mary Howitt, The Desolation of Eyam, London, 1827; 'Cucklet Church' in Samuel Roberts, Eyam; Its Trials and Its Triumphs, Sheffield, 1834, pp.17-24. ${ }^{40}$ Rhodes, Peak Scenery; Ebenezer Rhodes, Derbyshire Tourist's Guide, London, 1837; William Adam, The Gem of the Peak, London, 1838; R. Ward, A Guide to the Peak of Derbyshire, 7th edn., Birmingham, 1827.

${ }^{41}$ Roberts, Eyam; Spencer T. Hall, The Peak and the Plain: Scenes in Woodland, Field, and Mountain, London, 1853; Wood, Eyam; William Mompesson, The three following letters... are here reprinted ... at the expense of a Parishioner of Eyam, n.p.,1866.

${ }^{42}$ Roland and Emmott first appear as nameless characters in John Holland's poem and are described in most later accounts. In 1888, they are even the subject of a lengthy poem in its own right: Holland, Village, pp.11-12; The Tale of Eyam; or, a Story of the Plague in Derbyshire: And Other Poems by an Old Blue, Derby, 1888.

${ }^{43}$ Rhodes, Peak Scenery, p.40. Similar scenes are found in John Wilson, The City of the Plague, and Other Poems, Edinburgh, 1816. On Victorian attitudes to burial, see Ruth Richardson, Death, Dissection and the Destitute, London, 1987.

${ }^{44}$ Philippa Levine, The Amateur and the Professional: Antiquarians, Historians and Archaeologists in Victorian England, 1838-1886, Cambridge, 1986.

${ }^{45}$ Holland, Eyam, pp.26-9.
} 
letters, to communal memory or straightforward fiction, facilitate the untroubled expansion in scale. The common narrative structure that resulted amounted to an anecdotal patchwork of sub-plots or miniatures in which ambiguities could be left hanging, and contradictions - such as the fraught tension between marital and maternal ideals implicit in Catherine Mompesson's decision - could be ignored.

This expansion of interest in Eyam was part of a wider literary and historical fascination with past epidemics in the nineteenth century. ${ }^{46}$ Literary fashions played a part in this: William and Mary Howitt's poetic account of the epidemic was written soon after they had read John Wilson's 'beautiful' epic poem, City of the Plague, (1821), which had helped galvanise literary interest in plague. ${ }^{47}$ It was also closely related to contemporary experiences of disease. Late eighteenth and nineteenth century foreign epidemics, particularly the yellow fever epidemics that affected the United States in the 1790s, were widely discussed. ${ }^{48}$ Plague itself had become a disease of distant countries rather than a near threat. However, this itself triggered interest in the disease when it became the focus of the debate - largely conducted through discussions of historical epidemics - about disease causation and the usefulness of quarantine that spilled into the quarterly press and Parliament in the 1810 s and 1820s. From 1832, interest was sharpened by the successive epidemics of cholera that provided their own dystopic image of mass death, albeit largely contained among the urban poor. In turn, this new context

\footnotetext{
${ }^{46}$ Christine M. Boeckl, Images of Plague and Pestilence: Iconography and Iconology, Kirksville, 2000, ch. 6.

${ }^{47}$ Mary Howitt, Mary Howitt: An Autobiography, Boston, 1889, p.179. See also: H. Southern, 'Defoe's History of the Plague', The Retrospective Review, 6 (1822), p.19. ${ }^{48}$ The yellow fever epidemic also prompted a number of publications examining the events of past epidemics, notably N. Webster, A Brief History of Epidemic and Pestilential Diseases, 2 vols., Hartford, 1799. Abstracts of Defoe's Journal were also published: Pathetic History of the Plague in London, in the Year 1665, Charlestown, 1795; An Account of the Rise, Progress, and Termination, of the Malignant Ever, Lately Prevalent in Philadelphia. Briefly Stated from Authentic Documents, Philadelphia, 1793, pp. 3-12.
} 
influenced views of Eyam. As the introduction to a history of the epidemic published two years after the outbreak of cholera noted: 'From the recent visitation of the incomprehensible and destructive cholera...we are becoming more capable of duly appreciating what the effects of the plague must have been. ${ }^{49}$ By the 1870 s, Eyam was one of the central elements of what had come to constitute the epidemic history of Britain, along with the Black Death and the Great Plague of 1665. As the author of an article on the plague in Russia noted in The Times in 1879: 'Even the most passing glance at the history of the plague of 1665 would be incomplete without some reference to the outbreak in the village of Eyam in Derbyshire. ${ }^{50}$

The spate of epidemic histories in the nineteenth century was characterised by what Faye Getz aptly termed a 'gothic epidemiology' in her acute discussion of the 'Black Death industry' that emerged in the wake of Justin Hecker's History of the Black Death (1832). ${ }^{51}$ Many aspects of Getz's gothic model of plague history are apparent in accounts of Eyam. Most obviously, Eyam is a heroic narrative about 'extremes of behaviour' which highlights suffering and redemption. It too was 'rediscovered' after being nearly forgotten. Like Hecker, writers on Eyam present plague as beyond human comprehension. In addition, they share an interest in the exotic and medieval: descriptions of Eyam invoke chronologically distant references, such as quotations from the poetry of Ossian, and references to Druid stones and Vikings. ${ }^{52}$

\footnotetext{
${ }^{49}$ Roberts, Eyam, p.4. B. G. Babington made much the same point when prefacing his translation of J. F. C. Hecker, The Black Death in the Fourteenth Century, trans. B. G. Babington, London, 1833, v.

50 'The Plague', The Times, 30 Jan 1879, p.3.

${ }^{51}$ Faye Getz, 'Death and the Silver Lining: Meaning, Continuity, and Revolutionary Change in Histories of Medieval Plague', Journal of the History of Biology 24:3, 1991, p.277.

52 Wood, Eyam, 1st edn., pp.48, 55, 67, 80; Hall, Peak and Plain, p.314; Howitts, Desolation, pp.7-8.
} 
However, the story of Eyam developed in ways that were somewhat different to the histories of the Black Death that Getz analysed. Most obviously, it suggests a broader, less cholera-centred process occurring in the historiography of disease. Unlike the early Black Death histories, accounts of Eyam was largely produced by poets, writers, and local historians - not doctors. Moreover, early curiosity about Eyam indicates that, at least in England, the boom in popular interest in the Black Death rode on the back of an existing fascination with the history of epidemics predating cholera as well as Hecker's work. Beyond this, the literary and historical unfolding of the Eyam story also makes clear how epidemic disease was integrated into the image of the English past as a context within which moral and sentimental stories could be explored. Epidemics had been largely ignored in eighteenth century histories, something that seemed 'highly extraordinary' by the $1830 \mathrm{~s} .{ }^{53}$ By then, interest in plagues was firmly rooted in the same empathetic interpretation of past disasters that was developed by the Sewards for Eyam. This is also visible in the nineteenth century revival of other accounts of plague, such as Defoe's Journal. The editor of one edition of the Journal, for example, expressed precisely the balance of public and private interest that Anna Seward had emphasised in the Eyam story. He noted that there is 'no subject' that possesses 'in a greater degree the power to harrow up the feelings' than a city's devastation by plague. Yet he felt that its 'stronger claim upon our feelings', was its display of:

how the dearest and most cherished objects of affection and love were torn from their friends, and how all those thousand little kindnesses of domestic life which constitute so large a portion of

\footnotetext{
${ }^{53}$ Daniel Defoe, A Journal of the Plague Year, (ed) E. W. Brayley, London, 1835, p.xv. Plague was not, of course, ignored in the various medical books which developed arguments about disease through historical exemplification.
} 
human happiness, were forgotten in the midst of horrors so appalling $^{54}$

Eyam's story was more optimistic, but both reveal the debt in plague literature and histories to sentimental concerns with the too-easily destroyed emotional ties of family and society. ${ }^{55}$

Perhaps unsurprisingly given its early relationship to a defence of national identity, accounts of the Eyam plague from the first half of the nineteenth century are also marked by the persistence of political themes, some with implications for contemporary public health practices. Alongside the omnipresent romantic and sentimental theme ran a nostalgia for a lost time of pastoral authority and social order before sectarian diversity and industrialisation. Authors noted how Mompesson's will 'had the force and effect of a legislative enactment' and he was 'regarded with reverence and obeyed with alacrity. ${ }^{56}$ Although Quakers, William and Mary Howitt's description of his role in the decision to isolate the village is generally representative of descriptions of the heroic priest. In their poem, The Desolation of Eyam (1827), the villagers are on the verge of mass despair and flight until Mompesson appears to calm them. Then, the villagers:

Heard, and they obeyed, - for simple-hearted, He was to them their wisdom and their tower. ${ }^{57}$

\footnotetext{
${ }^{54}$ Daniel Defoe, The History of the Great Plague in London, in the Year 1665, London, 1832, pp.iii-iv.

${ }^{55}$ Similar plague romances include the popular novel by W. H. Ainsworth: Old Saint Paul's: A Tale of the Plague and the Fire, London, 1847, in which a dilettante romance is mingled with a very loose rendition of Defoe's Preparations against the Plague.

${ }^{56}$ Rhodes, Peak Scenery, p.35. See: Chandler, A Dream of Order, pp.28-30, 128-43; Raymond Chapman, The Sense of the Past in Victorian Literature, London, 1986, pp.34-37

${ }^{57}$ Howitts, Desolation, pp.17-19. Such descriptions may help account for a review criticizing their work as 'anti-quackerish': Howitt, Mary Howitt, p. 198. William Howitt later numbered Mompesson among those 'humble country parsons who have toiled in their obscure allotments with ... zeal and like humility' who are 'excellent men' despite being 'involved in the intricacies of the worst systems' of priestcraft: William Howitt, $A$
} 
Similar hierarchical visions of clerical wisdom and morality leading an unlearned, rustic flock appear repeatedly. The villagers' dependency is idealised as part of a passing world of organic communities, the loss of which grievously concerned many. ${ }^{58}$ Eyam was, it should be remembered, located on the moorland which separated Arkwright's mills at Matlock from Sheffield's burgeoning factories.

To this extent, descriptions of the Eyam plague were similar to representations of the middle ages as a period of unproblematic hierarchical order. ${ }^{59}$ However, it gained a more specific meaning in relation to contemporary epidemics. Eyam had, from Mead's account onwards, featured as an example in debates over contagion and public health. Its extreme mortality, apparent path of contagion via goods, and the success of its quarantine made Eyam a perfect example for those laymen and members of the medical establishment supporting plague's contagiousness. In 1825, for example, William MacMichael devoted a lengthy section of his tract attacking the anti-contagionist campaign against quarantine to lengthy quotations from Mead and William Seward's accounts. ${ }^{60}$ Eyam acquired new resonance, however, with the arrival of cholera. In this, it provided an even more salutary example than Defoe's plague works, which were republished along with many other descriptions

Popular History of Priestcraft in All Ages and Nations, 3rd edn., London, 1834, pp.366, 380.

${ }^{58}$ Chapman, Sense of the Past, pp.145-62. This is also apparent in nineteenth century literature on craft guilds, for example: L. Toulmin-Smith, English Guilds, London, 1870.

${ }^{59}$ Chapman, Sense of the Past; Ranger and Hobsbawm, Invention of Tradition.

${ }^{60}$ W. MacMichael, A Brief Sketch of the Progress of Opinion Upon the Subject of Contagion; with Some Remarks on Quarantine, London, 1825, pp. 22-6. See also: John Howard, An Account of the Principal Lazarettos in Europe, 2nd edn., London, 1791, pp.24-5. The contingent-contagionist Thomas Hancock, in contrast, concluded that 'something is omitted' in the account of Eyam to explain the epidemic, while John Mitchell dismissed 'marvellous tales' of contagion by goods in his evidence to the House of Commons committee on contagion: T. Hancock, Researches into the Laws and Phenomena of Pestilence, London, 1821, p.213; House of Commons, Report from the Select Committee Appointed to Consider the Validity of the Doctrine of Contagion in the Plague, Sessional Papers, vol. 2, doc 449 (1819), pp.90-91. On this debate: Margaret Pelling, Cholera, Fever and English Medicine, 1825-1865, Oxford, 1978. 
of past plagues considered 'useful' as well as entertaining. ${ }^{61}$ Reflections on the Great Plague of 1665 , it was suggested, might 'awaken others in the mind of the reader... to make him regard with reverence the operations of Divine Providence'. ${ }^{62}$ Eyam shared this spiritual characteristic, but it also formed the exception to the rule in medical, historical and fictional accounts that plague produced 'a total dissolution of the bonds of society'. ${ }^{63}$ The villagers' willing subordination of individual interest to the greater good offered an implicit criticism of resistance to public health measures. The villagers had even been willing to bury the dead in un-consecrated land with little ceremony, a practice that attracted great public resistance when enforced by the Boards of Health in the 1830s. Mompesson was, as John Mason Neale noted in a poetic description of plague written at the time of the second major cholera epidemic in 1845, the exemplar of active ministry - of the priests 'in the street' who 'go on from death to death with never tiring feet' - that 'will probably occur to the reader's memory'. ${ }^{64}$ Despite relatively low rates of

\footnotetext{
${ }^{61}$ [D. Defoe], Narratives of Two Families Exposed to the Great Plague of London, A.D. 1665; with Conversations on Religious Preparation for Pestilence, ed. J. Scott (London, 1832). Similar descriptions of plagues include: 'The Great Plague in the Fourteenth Century', Fraser's Magazine, 5, 1832, pp.415-19; J. Ireland, The Plague of Marseilles in the Year 1720, London, 1834; 'The Plague in Olden Times', Chambers Journal of Popular Literature, Science and Arts, London, 1859, pp.221, 232. See also: Boekl, Plague, pp.145

${ }^{62} \mathrm{H}$. Stebbing, 'Introduction' to D. Defoe, The History of the Great Plague in London, in the Year 1665, ed. H. Stebbing, London, ca. 1835, pp.xxx-xxxi. See also: D. Defoe, $A$ Journal of the Plague Year, ed. E. W. Brayley, London, 1835, pp.xvi-xvii; J. F. C. Hecker, The Black Death in the Fourteenth Century, trans. B. G. Babington, London, 1833, v.

63 'The Great Plague in the Fourteenth Century', Fraser's Magazine, 5 (1832), p.417. Similar accounts of plague's destruction of order appear in: Wilson, City of the plague, pp.13-15; Charles MacLean, Summary of Facts and Inferences, Respecting the Causes, Proper and Adventitious, of Plague and Other Pestilential Diseases, London, 1820, pp. 13-14; H. Southern, 'Writers on the Plague', Retrospective Review, 7 (1823), p.220; 'Plague, a Contagious Disease', The Quarterly Review, 33 (1825), pp.223-4; 'Plague and Pestilence', The Cornhill Magazine, 11 (1865), pp.591-603.

${ }^{64}$ Neale, A Mirror of Faith, p.141.
} 
death, discipline had been maintained in Eyam, in contrast to the disturbances which broke out against cholera regulations. ${ }^{65}$

Although increasingly embedded within a new national chronology of epidemics, the reproduction of the Eyam story was inflected by local, as much as national, concerns for much of the nineteenth century. Eyam had, from the beginning, been a subject that received most attention from authors with a close relationship and affinity to the locality. One consequence of this was that local tensions between Anglicans and Independents were expressed through a debate over the role of Thomas Stanley that emerged in the early nineteenth century and continued well into the twentieth. ${ }^{66} \mathrm{~A}$ more striking result of the local investment in the plague story was the avoidance of comment on the meaning of plague. To be sure, descriptions of the epidemic are richly gothic, much as Getz noted in Hecker's History. ${ }^{67}$ In poems, plague is, for example, personified as a demonic agent, a 'sable demon' throwing 'darts at midnight'. ${ }^{68}$ Similarly, in histories and guidebooks plague might 'burst forth' from the

\footnotetext{
${ }^{65}$ A similar purpose is apparent in: 'Great Plague', Fraser's Magazine. On resistance to regulations in nearby Sheffield: J. Stokes, The History of the Cholera Epidemic of 1832 in Sheffield, Sheffield, 1921, pp. 23-24, 31-32. The attacks of the London 'mob' on Board officials were eloquently criticized by Algernon Greville: The Greville Memoirs, ed. H. Reeve, 3 parts, London, 1874-87, part 2, 278-9. More generally, see: R. J. Morris, Cholera 1832: The Social Response to an Epidemic, London, 1976, pp.108114; M. Durey, The Return of the Plague: British Society and the Cholera, 1831-2, Dublin, 1979, pp. 156-84; Richardson, Death, pp. 223-30. Disturbances were on a larger scale on the continent: P. Baldwin, Contagion and the State in Europe, 18301930, Cambridge, 1999, pp. 62-5, 115-6.

${ }^{66}$ On tense relations between chapel and church: Derbyshire Record Office (DRO)., D2602 A/P1, 21/1, pp.8-9. Opinions on Stanley include: Holland, Village, p.13; Roberts, Eyam (1834), p.8; Wood, History, $3^{\text {rd }}$ edn, p.120. A memorial to Stanley was erected in 1891, but the feud continued. The local historian and Methodist lay preacher Clarence Daniel's suggestion that Mompesson might have thought himself too good for Eyam, seems to have inspired R.M.B[eaumont], grandson of one of Eyam's nineteenth century Anglican vicars, to publish a defence of Mompesson 'the hero' in 1979: Clarence Daniel, History of Eyam, Sheffield, 1932; R. M. B., The Reverend William Mompesson, 1638-1708, Hero of Eyam, Southwell, 1979, p.3.

${ }^{67}$ Getz, 'Black Death', p.277.

${ }^{68}$ Holland, Village of Eyam, p.15. See also: Howitts, Desolation, p.15.
} 
clothing chest to claim the dead as its 'victims' ${ }^{69}$ However, this image of the epidemic as a conflict between the villagers and a disease-animal construct gives the plague a much narrower plot than the providential interpretation that was dominant in the seventeenth century. ${ }^{70}$ In late eighteenth and nineteenth century accounts, by contrast, such general questions of causation are evaded by reference to the immediate carrier: the cloth from London. Even where Mompesson is figured as a modern prophet, standing like Aaron 'between the living and the dead', sin as cause is circumvented. ${ }^{71}$ This avoidance of providence might, perhaps, be a product of secularisation. Nonetheless, the contrast with Wilson's City of the Plague, in which divine judgement is heavily emphasised, or even contemporary associations of sin, moral dissolution and cholera, suggests that the avoidance of questions of guilt reflects the influence of local authors who are unwilling to attribute any taint to the village. ${ }^{72}$ That the evangelically-inclined might disagree with this exculpation of the village is suggested by William Wood's decision to explicitly deny that the plague could have been caused by various communal sins in the village.

\section{The Epidemic And The Village}

Eyam's fame in the nineteenth century might seem, if anything, over determined: the plague story appealed as a tragic romance, as a historical anecdote rich in the nostalgia for order, community and responsibility, and as a celebration of heroic, Christian manhood and womanhood. However, literary success did not necessarily equate to the

\footnotetext{
${ }^{69}$ Rhodes, Peak Scenery, p.39.

${ }^{70}$ Alexandra Walsham, Providence in Early Modern England, Oxford, 1999; Keith Thomas, Religion and the decline of magic, London, 1971.

${ }^{71}$ Holland, Village of Eyam, p. 17; Roberts, Eyam, p.1. The reference is to Numbers 16.48 .
} 
emergence of the village as a heritage site and tourist destination. For this to happen, the textual phenomenon had to mapped onto the site of the village and its economy. Here, again, local agency was to be highly significant, as it had been in the literary transformations which preceded and enabled it.

The process of imaginative reconstruction can again be clearly traced. The crucial moment was the bicentenary of the plague in 1866. Before that, few of the inhabitants of Eyam seem to have given much consideration to the plague and its remains beyond blaming a fever outbreak in 1755 on excavated contagious material. ${ }^{73}$ In the early 1800s, tombstones from plague graves were being recycled by villagers for flooring and the Cucklet church had been forgotten. The Riley Graves one of the most prominent burial sites - was only saved from the plough when a local gentleman bought the plot to preserve 'that character of sacredness which it never should have lost'. ${ }^{74}$ Through the successful ceremony and its rewards, the bicentenary reshaped the village's attitude to its plague past. It created an appreciation of the potential economic and cultural wealth of its heritage, a welcome opportunity against a backdrop of local poverty and slowly dwindling population as families moved away to work in the growing manufacturing districts. ${ }^{75}$

Eyam's plague celebrations were an overtly invented tradition, of the kind that Hobsbawm identified multiplying in this period. ${ }^{76}$ The rector, John Green's description of the bicentenary describes how he proposed a public event because the anniversary would be the moment 'in which

\footnotetext{
${ }^{72}$ Wilson, City of the Plague. Plague as judgement also features in Pelham Knott, $A$ Tale of the Plague; the Old Jackdaw; and Other Poems, Glasgow, 1846. See also: Richards, Death, p.227; Morris, Cholera, pp.132-55.

${ }^{73}$ Seward, Poetical Works, p.clxv.

${ }^{74}$ Rhodes, Peak Scenery, p.44-5, 52.

${ }^{75}$ The local lead mines had failed in 1821, and movements to manufacturing districts explained the fall in population in 1831: Census of Great Britain, 1831, London, 1832; Census of Great Britain, 1851, London, 1852.
} 
we should be likely to interest the general public and the Gentry of the County \& get them to help us'. ${ }^{77}$ (Among Eyam's 'many wants' was a church in need of restoration, and revenue for this was at the centre of the celebration from the outset.) Lacking precedent, he invented a commemorative process, including a triad of memorial sermons. He even selected the date on which to remember the year-long epidemic. In this the literary tradition helped: he chose 26 August because it was closest to the burial date of Catherine Mompesson. He also ensured the story was freshly circulated by printing and advertising 500 copies of the 'Story of the Plague of Eyam'. ${ }^{78}$ Green's timing was fortuitous. Not only did the bicentenary come after years of publications on the plague, it fell in the immediate aftermath of a major cattle plague, which had turned many farmers from anti-contagionists into enthusiasts for quarantines; it also coincided with a cholera epidemic. ${ }^{79}$ It need hardly be said that the event was a great success.

From 1866, the plague became the centre point of the ritual year of the community. By the 1880s, remembrance services were held annually. These grew in size until they had to be shifted to the symbolic site of the delft, the location of Mompesson's services during the plague. ${ }^{80}$ Other aspects of the village's communal life were also caught up in the

\footnotetext{
${ }^{76}$ E. Hobsbawm, 'Mass-Producing Traditions: Europe, 1870-1914', in E. J. Hobsbawm and T. O. Ranger (ed.), The Invention of Tradition, Cambridge, 1983, pp.263-308. ${ }^{77}$ Presented with a choice between a new school and church improvement, the villagers decided to restore and enlarge the 'Parish Church as a memorial of the Plague and the Reverend W. Mompesson \& W. Stanley' - a careful attempt to circumvent differences about the respective importance of the two plague heroes. Green recorded these events: DRO, D2602 A/P1, 21/1, pp.42-43.

${ }^{78}$ The collection raised $£ 143 \mathrm{~s} 5 \mathrm{~d}$.

${ }^{79}$ Michael Worboys, Spreading Germs: Disease, Theories, and Medical Practice in Britain, 1865-1900, Cambridge, 2000, pp. 49-51. A day of humiliation because of the cattle plague had been held on 7 March 1866: DRO., D2602 A/P1, 21/1, p.55.

${ }^{80}$ There is some uncertainty about the timing of the move to the Delft. Fletcher suggested 1905 in his guidebook of 1924, but in 1979 R.M.B claimed his grandfather, E. Hacking had moved the services to the Delft in 1888, a date also given in The Times in 1934: Rev. J. M. J. Fletcher, The Plague-Stricken Derbyshire Village or, What to See
} 
epidemic's coat-tails: the annual well dressing regularly included a plague theme among its decorations, for example. This set of rituals facilitated the village's emergence as popular destination for the new phenomenon of mass tourism. By the 1930s, Eyam was one of the 'musts' for a visitor to Derbyshire and the remembrance service was a key part of the tourist itinerary. In 1934 it was reported that 10,000 people attended. ${ }^{81}$ As tourism grew, the demand for visible signs of the calamity led to an artificial material history being created. The church acquired a chest which was questionably labelled as the box in which plague came to the village. ${ }^{82}$ The fabric of the village was even spuriously inscribed with the story of the plague. During the Festival of Britain in 1951, tablets were attached to buildings around the village to indicate their connection with the plague, despite their being no 'actual documentary or other evidence' to verify the links. ${ }^{83}$

The success of the village in promoting itself was apparent at the tercentenary in 1966. Now the importance of the Eyam plague went unquestioned. Messages of goodwill arrived from the Bishop of Derby and the Duke of Devonshire. The Lord Mayor of London even sent a guarded apology for what 'history implies' was his city's role in sending plague to Eyam. ${ }^{84}$ In place of the rural dean of 1866, now the Archbishop of York gave the sermon. Although the village was described by one resident as 'national shrine of pilgrimage', the economic significance of Eyam's heritage to the modern community was barely concealed. ${ }^{85}$ Some things remained the same: donations were for 'urgent repairs to the

in and around Eyam, 3rd edn., Tideswell, 1924; R. M. B., Mompesson, p.3. The 1925 service was reported with a photo-story in The Observer, 30 Aug 1925, p.12.

81 'Deliverance from 1665 Plague', The Times, 27 Aug 1934, p.7. Similar stories include: 'The Glorious Memory of Eyam', The Observer, 30 Aug 1925, p.12;

'Pilgrimage to Eyam', The Times (31 July 1957), p.10.

82 Daniel, Eyam, 1932, p.44.

${ }^{83}$ Clarence Daniel, The Story of Eyam Plague with a Guide to the Village, revised edn., Eyam, 1985, chapter 2.

${ }^{84}$ Eyam Plague Tercentenary, Eyam, 1965. 
Church', as in 1866. But a century of tourism had left a plague tourism infrastructure. Adverts for the Miners' Arms even assured potential visitors that they would be 'in the Worst Hit Area of the Village' with 'A Communal burial Ground at the Rear'.

\section{Plague Without A Hero}

Ironically, as Eyam was transforming itself into an epidemic themepark with a secure place in the tourist itinerary of the midlands, its literary representations began to take on a less straightforwardly heroic form. For most of the nineteenth century, the story of Eyam had grown in a haphazard, uncritical manner. The ragbag version this eventually produced did not disappear overnight, indeed it continues to be republished often in a similar form today.$^{86}$ However, it was now subjected to an increasing degree of critical scrutiny and suspicion. In part, this more cautious appraisal of the Eyam story was indebted to the growing dominance of scholarly practices in historical discourse, and the associated turn against invention and empathetic fabrication. By the late nineteenth century, Wood had himself begun to revise the epistemological status of some parts of his History, re-labelling episodes recounted as gospel in early editions as 'Traditions of the Plague'. ${ }^{87}$ However, new accounts of historical plagues were fundamentally affected by a more specific development: the discovery of the plague bacillus and its rat/flea vector at the start of the twentieth century. ${ }^{88}$ This ushered in an era in which descriptions of the plague at Eyam were beset by an

\footnotetext{
85 Daniel, Eyam (1985), chapter 1.

${ }^{86}$ For example: G. Turbutt, A History of Derbyshire, 4 vols. Cardiff, 1999, iii, 1186-90.

${ }^{87}$ Contrast the third and fifth editions for example: Wood, History, $3^{\text {rd }}$ edn., pp.93ff; Wood, History, $5^{\text {th }}$ edn, p.101.

${ }^{88}$ Andrew Cunningham, 'Transforming Plague: The Laboratory and the Identity of Infectious Disease', in Andrew Cunningham and Perry Williams (eds), The Laboratory Revolution in Medicine, Cambridge, 1992, pp.209-44; Worboys, Spreading Germs.
} 
oppressive and anachronistic irony, similar in some ways to that Paul Fussell identified in writing and memories on the Great War. ${ }^{89}$ Authors scattered rats across both historical and fictional works on plague as emblems of the futility of pre-modern therapies and precautions: the contemporary failure to identify this agent - seeming so obvious in retrospect - was damning. ${ }^{90}$ In Eyam's case, there was an additional factor at work behind the new scepticism: a long-standing learned and popular questioning of quarantine and isolation as ineffective, costly and potentially dangerous, a position which had eventually led to Britain reforming its port sanitary controls in the later nineteenth century, was slowly mapped onto literary and historical evaluations of the village's voluntary isolation. ${ }^{91}$ This process appears to have begun with the historical epidemiologist Charles Creighton, who despite his own rejection of bacteriological theory concluded his description of what he termed 'the most famous of all English plagues' with the judgement that, while undoubtedly heroic:

the villagers of Eyam were sacrificed, all the same, to an idea, and to an idea which we may now say was not scientifically sound. ${ }^{92}$

From the 1930s onwards it was common for the village's experience to be seen as tragic futility or foolishness, rather than tragic necessity as had been the norm in the nineteenth century. ${ }^{93}$

\footnotetext{
${ }^{89}$ Paul Fussell, The Great War and Modern Memory, Oxford, 1975.

${ }^{90}$ For Eyam examples: Eyam and the plague: a guide to the village, Derby, n.d., p.2; Joyce Dennys, Isolation at Eyam, London, 1954, p.9.

${ }_{91}$ Worboys, Spreading Germs, pp.240-2, 247-8; Peter Baldwin, Contagion and the State in Europe, 1830-1930, Cambridge, 1999; Pelling, Cholera, pp.26-29.

${ }^{92}$ Charles Creighton, A History of Epidemics in Britain, 2 vols., Cambridge, 1891, i, pp.682, 687.

${ }_{93}$ W.R.B.. 'Editorials: William Mompesson, 1639-1709', Annals of Medical History, 3rd ser., 1, 1939, p.564; Marjorie Bowen, God and the Wedding Dress, London, 1938; Batho, 'Plague at Eyam', pp.81-91; Daniel, Eyam, 1985.
} 
This re-evaluation of isolation had greatest consequences for Mompesson's reputation. He undoubtedly remained a hero, but he lost some of his lustre. As an editorial in the semi-popular medical journal Annals of Medical History suggested:

inspired by the loftiest motives, [Mompesson] arrogated to himself the responsibility for sacrificing the villagers to an idea which we in our maturity have come to regard as scientifically unsound. ${ }^{94}$

The notion that Mompesson could, ultimately, have been wrong fitted into a broader move against the Victorian idealisation of his character. Authors in the twentieth century turned against the singleminded conviction, faith and authority of nineteenth-century representations of Mompesson, as these characteristics became increasingly unpalatable. In its place they imagined a more flawed heroism. In fictional accounts, the plague sometimes became a journey of spiritual purification in which Mompesson starts as a troubled character. In Don Taylor's play The Roses of Eyam (1970) he is overzealous - 'a youngster, full of arrogance and spleen, who spits in the dust as we pass', one villager comments; in Marjorie Bowen's plague novel God and the Wedding Dress (1938) he is overly ambitious and worldly. ${ }^{95}$ In both, the plague leaves Mompesson a better man. This remoulding of Mompesson-the-hero coincided with a gradual recognition of some of the awkward elements in the traditional story about Eyam. For example, the ambiguity which surrounds Mompesson's removal of his own children is identified and resolved in Taylor's play when the villagers explicitly forgive their guilt wracked priest. A similar imperative marks some twentieth century histories of the plague: while Wood still provides the party line,

\footnotetext{
${ }^{94}$ W.R.B., 'Mompesson', p.564

${ }^{95}$ Don Taylor, The Roses of Eyam, London, 1976, p.9; Bowen, God and the Wedding Dress. Taylor's play was performed first in September 1970 at the Northcott Theatre in Exeter, and later successfully televised.
} 
some of the questions around the authenticity of elements of the story discussed above began to be raised ${ }^{96}$ This uncertainty is given graphic form in Eyam Museum, where many of the nineteenth-century stories that continue to feature are relegated to smaller type on display panels.

Strikingly, the shift away from the hagiography of the Mompessons is underlined by the date of the commemoration service now being justified as being closest to the start of the plague, not to Catherine's death.

This sceptical turn reached its highpoint in one of the more original and unusual recent reiterations of the Eyam story. In 1995, the writers of Eyam: A Musical translated the plague into a pop-opera with a social conscience. Unusually, they represented Eyam as a working-class mining community, with lives shaped by hard and dangerous work and strong ties which echo the troubled English coal mining towns of the 1980s and 1990s. Old tropes are inverted or discarded. The villagers take a dismissive, even hostile, attitude to their new rector until near the end of the plague. Some blame him for bringing the disease. Mompesson's arguments about isolation fail to convince them and, in a singular reversal of earlier accounts, the decision to isolate the village almost goes to a community vote. This time Mompesson's children don't escape: Catherine reaches the borders of the village with them but is unable to betray the community. Her return turns the quarantine argument. Mompesson is reduced to a troubled man, riven with uncertainty, whose will breaks after his wife's death and has to be shored up by villagers. Throughout the musical, the question of whether isolation was pointless or necessary remains to some degree open - and the fact that neighbouring communities will turn away any who leave is strongly made. Given that the musical was written by the librettist of Martin Guerre,

\footnotetext{
${ }^{96}$ Batho, 'Plague Reconsidered'; John G. Clifford, Eyam, revised edn., Eyam, 2003. This can also be seen in Eyam Museum; the displays are largely based on Clifford's book.
} 
another dark interpretation of early-modern lives, this alteration in perspective is perhaps predictable. However, the musical seems to take several general trends in accounts of Eyam to their natural conclusion, trends which are also visible in other recent fictional interpretations. ${ }^{97}$ In choosing to introduce elements of scapegoating, in questioning leadership, and highlighting marginalisation, such versions of the plague story suggest the impact of AIDS on earlier more optimistic expectations about human responses to disease, as well as the cumulative impact of a changed historical approach which gave greater credibility to the view from below.

\section{Conclusion}

Despite recent shifts in emphasis, Eyam's plague remains one of the most pervasive images of epidemic disease in English history, while its popularity as a tourist destination is sufficient to stretch the ability of the village to accommodate demand. ${ }^{98}$ As has been shown here, it is also among the most deliberately constructed stories: although the story has been widely circulated in the last two centuries, it is loosely grounded in scanty evidence and it became well-known only after a century in which it was almost forgotten. The invention of the plague at Eyam allows us to trace the evolution and circulation of the story of an epidemic in unusual detail. In this sense, accounts of Eyam plague inevitably tell us more about late eighteenth and nineteenth century concerns with locality and the past than they do of the epidemic itself. The process of creation and reproduction exposed here demonstrates the interaction of literary and historical fashion, political contingency, popular aetiology, and local

\footnotetext{
${ }^{97}$ In particular, see Geraldine Brooks' novel, where scapegoating and marginalisation are also significant issues: Geraldine Brooks, Year of Wonders, London, 2002.
} 
interest in moulding a history that conveyed ideas of identity and duty, romantic love and heroic behaviour - and, in the process, sustain a significant tourist trade - as it entertained and fascinated readers and visitors with its gory tragedy. In this, the relationship between text and space was dynamic, with the events of the plague once rediscovered being revivified in the location of the epidemic. If some of this was a conscious attempt to invent links, to fill in the gaps, as in the attribution of roles to particular houses through plaques, it soon became indistinguishable from the main body of plague history in the village. Much recent scholarship has explored the role of heritage and history in the expression of identities and values among national or politicallydefined groups, often with particular attention to the active creation of symbolic practices and sites to construct or underpin identities. ${ }^{99}$ Eyam, by contrast, underlines the significance of local contingency and investment in the production of such histories. Local needs and concerns provided the impetus behind the promotion of the village as a heritage sight, just as local literary figures - although in the Seward's case certainly acting in a national arena - gave the story its initial form and publicity.

Eyam plague was not, of course, a romantic interlude in village life: the bloody weight of the epidemic is unavoidably argued by the death roll of the parish register, whatever the exact proportions involved. The role of the villagers, Mompesson, Stanley and their neighbours may or may not have saved the area from further infection, but that this question must remain unresolved hardly diminishes the horror of the events they experienced. This very extremity of experience which gives the story its

\footnotetext{
${ }^{98}$ Christopher W. Antonsen, "'Its Character Shall Not Be Destroyed": Narrative, Heritage, and Tourism in the Plague Village', Ohio State University, Ph.D. thesis, 2001. ${ }_{99}$ David Lowenthal, The Heritage Crusade and the Spoils of History, Cambridge, 1997; Patrick Wright, On Living in an Old Country: The National Past in Contemporary Britain,
} 
enduring interest must also give us greatest pause for thought when seeking to understand such events or interpret the heroic or romantic narratives that continue to permeate accounts of epidemics, even in the inverted form that has appeared more recently. It is, to this extent, salutary to contrast the empathetic freedom felt by interpreters of such distant epidemics, and their willingness to judge individuals' failings or heroism, with the recognition of the limits of representation that historians and others have found in addressing more recent traumatic events, such as genocide, which constantly escape our attempt to grasp and describe them in a satisfying way. ${ }^{100}$ As William Mompesson noted after the epidemic had drawn to a close: 'The condition of the place has been so sad, that I persuade myself it did exceed all history and example'.

London, 1985; Robert Hewison, The Heritage Industry: Britain in a Climate of Decline, London, 1987; Hobsbawm and Ranger, The Invention of Tradition.

100 See: Cathy Caruth, Unclaimed Experience: Trauma, Narrative, and History, Baltimore, 1996. 


\section{LONDON SCHOOL OF ECONOMICS}

\section{DEPARTMENT OF ECONOMIC HISTORY}

WORKING PAPERS IN - THE NATURE OF EVIDENCE: HOW WELL DO "FACTS" TRAVEL?

For further copies of this, and to see other titles in the department's group of working paper series, visit our website at:

http://www.Ise.ac.uk/collections/economichistory/

01/05: Transferring Technical Knowledge and Innovating in Europe, c.1200-c.1800 Stephan R. Epstein

02/05: A Dreadful Heritage: Interpreting Epidemic Disease at Eyam, 1666-2000

Patrick Wallis 